\title{
Increasing the length of EM-9 interstock enhances production efficiency in Imperial Gala apples
}

\author{
José Luiz Marcon Filhol, Aike Anneliese Kretzschmarl, Joseane de Souza Hipólitol, \\ Andrea De Rossi Rufato ${ }^{2}$, Leo Rufato ${ }^{1}$, Douglas André Wurz ${ }^{3 *}$ (1) \\ $10.1590 / 0034-737 X 201966030003$
}

\begin{abstract}
The objective of this study was to evaluate the influence of different lengths of EM-9 interstock, on the production and fruit characteristics of Imperial Gala apples more than eight years old. This experiment was conducted in a commercial orchard located in Vacaria-RS, Brazil, situated at an altitude of $955 \mathrm{~m}$, during seasons 2005/06, 2007/08, 2010/11, 2011/12 and 2012/13. The treatments consisted of five lengths of EM-9 interstock $(10,15,20,25$ and $30 \mathrm{~cm})$ connecting the Marubakaido rootstock to the Imperial Gala scion. For production efficiency a positive correlation between increased efficiency and the length of interstock was observed. Likewise a positive correlation was also noted for quality parameters of the fruit; firmness and classification (Category 1). From this study we conclude that a EM-9 interstock of $30 \mathrm{~cm}$ on Marubakaido rootstock is the most suitable for the vigor control of Imperial Gala apples, it ensures greater production efficiency and firmer fruit.
\end{abstract}

Keywords: Mallus domestica; Marubakaido; rootstock; production; fruit quality.

\section{INTRODUCTION}

Brazilian apple production plays an important role in the international industry. In recent years, Brazil has exported more apples than imported. This is due to an evolution in the technologies used, in particular the production efficiency of orchards and industry infrastructure (Petri et al. 2011).

Now days fruit production involves obtaining smaller and more productive plants, which ca be improved by new combinations of rootstocks and scions (Fioravanço \& Lazzarotto, 2012). The apple tree has a large number of rootstocks which differ significantly in scion vigor, pathogen resistance and adaptation to different environmental conditions. The choice of rootstock is an important tool for managing sustainable fruit production, as it can allow intensification of orchards and improve the quality of the fruit (Gregory et al. 2013).

The lack of rootstocks adaptable to Brazilian conditions means the EM-9 and Marubakaido rootstocks (Prunus prunifolia (Greene) Shafer) are the most used. The combination of these rootstocks by technique of interstock combines the main characteristics of both, such as Marubakaido's adaptation to different soil types and resistance to aphid and collar rot along with induction to dwarf plants, early fruiting, high productions and fruit quality of the EM-9 rootstock (Denardi, 2006).

The interstock technique is applied to peach (Scarpare Filho et al 2000; Rufato et al. 2006; Telles et al. 2006; Tomaz et al. 2010), pear (Baciu et al. 2008), citrus (Girardi and Mourão Filho, 2006) and mango (Veloso, 2004). For apple, interstock allows the formation of less vigorous

Submitted on March 18th, 2019 and accepted on May 27th, 2019

${ }^{1}$ Universidade do Estado de Santa Catarina, Centro de Ciências Agroveterinárias, Lages, Santa Catarina, Brazil, marconfilho_jl@yahoo.com.br, aikeanneliese@yahoo.com.br, souzajose@ hotmail.com, leoruffato@yahoo.com.br

${ }^{2}$ Empresa Brasileira de Pesquisa Agropecuária, EMBRAPA Uva e Vinho, Vacaria, Rio Grande do Sul, Brazil, andrea.rufato@embrapa.br

${ }_{3}^{3}$ Instituto Federal de Educação, Ciência e Tecnologia de Santa Catarina, Canoinhas, Santa Catarina, Brazil. douglaswurz@hotmail.com

*Corresponding author: douglaswurz@hotmail.com 
plants (Samad et al. 1999; Vercammen et al. 2007; Di Vaio et al. 2009), with shorter juvenility (Bhat et al. 2011), greater productivity (Samad et al. 1999; Tojnko et al. 2004; Di Vaio et al. 2009) and higher fruit quality (Samad et al. 1999).

Increasing the length of interstock influences the growth of the canopy by reducing the vigor of plants (Rossi et al. 2003; Di Vaio et al. 2009; Marcon Filho et al. 2009). The fruit characteristics can also be affected by interstock/ rootstock combination, as these interfere with the absorption of water, nutrients and translocation of carbohydrates (Martínez-Ballesta et al. 2010), in this way the length of interstock used can modify fruit quality. Therefore the aim of the present study has been to evaluate the influence of length of EM-9 interstock on the production efficiency and fruit quality of Imperial Gala apples over eight years old and grafted on Marubakaido rootstock.

\section{MATERIALS AND METHODS}

The experiment was performed in a commercial orchard, located in the municipality of Vacaria, in the state of Rio Grande do Sul (RS), Brazil, during the production cycles 2005/06, 2007/08, 2010/11, 2011/12 and 2012/13. The experimental orchard was installed in the year 1999, with spacing of $4.5 \mathrm{~m} \times 1.25 \mathrm{~m}$. The seedlings were obtained by performing two double - slotted grafting grafts. The trainning system used was a central leader and the cultural practices (pruning, overcoming dormancy, fruit thinning and phytosanitary treatments) were carried out by the company according to the rules of the Integrated Production of Apple.

The treatments consisted of five lengths of the EM-9 interstock $(10 ; 15 ; 20 ; 25$ and $30 \mathrm{~cm})$, between the Marubakaido graft and the Imperial Gala scion. In all the years of conduction of the experiment were evaluated: a) production per plant $(\mathrm{kg})$, determined with the aid of a digital scale, performed at the time of harvest; B) productive efficiency $\left(\mathrm{kg} \mathrm{cm}^{-2}\right)$, calculated by the relation between the production per plant $(\mathrm{kg})$ and the area of the trunk section $\left(\mathrm{cm}^{2}\right)$ of the canopy cultivar, obtained by means of the longitudinal and transverse measurements of the planting line of the trunk diameter, calculated using the formula $\mathrm{A}=$ $(\pi \mathrm{d})^{2} / 4$, where $\mathrm{d}=$ diameter; and c) production efficiency $\left(\mathrm{kg} \mathrm{m}^{-3}\right)$, calculated by the relation between the production per plant $(\mathrm{kg})$ and the volume of the canopy $\left(\mathrm{m}^{3}\right)$ obtained by measuring the width and thickness of the crown and the height from the insertion point of the first branch in the trunk. The cumulative production $(\mathrm{kg})$ and the cumulative productive efficiency $\left(\mathrm{kg} \mathrm{cm}^{-2}\right)$, obtained by the sum of the means at each intergrain length, in the respective harvests were calculated with the results.
In addition to these variables, in the productive cycles 2010/11, 2011/12 and 2012/13, the physico-chemical characteristics of the fruits were evaluated: a) mass of the fruit (g) determined using a semi-analytical balance; B) firmer fruit $\left(\mathrm{kg} \mathrm{cm}^{-2}\right)$, determined using a manual penetrometer equipped with an $11 \mathrm{~mm}$ diameter ferrule. In each fruit, two readings were carried out on opposite sides, in the equatorial section of the fruit, after removal of the epidermis; c) soluble solids ( ${ }^{\circ}$ Brix), determined by digital refractometer for sugar model ITREFD-45 and d) category - CAT 1, CAT 2, CAT 3 - (\%), obtained by parameter proposed by the company, which considers the intensity of the red color and in relation to the area covered by the fruit, being classified in CAT 1 when the value exceeds the percentage of $60 \%$, CAT 2 when it was between the limits of 60 to $40 \%$, and CAT 3 when the values correspond to the range that is Between 20 and $40 \%$.

The experimental design was a randomized block design, with four replications and four plants per plot. Analysis of variance was performed by ANOVA and significance assessed using $\mathrm{P}=0.05$. Mean values were the effects of the treatments evaluated by polynomial regression through the WinSat program (Machado \& Conceição, 2003). Category data (CAT 1, CAT 2 and CAT 3) were transformed into sinewave " $\mathrm{x} / 100$.

\section{RESULTS AND DISCUSSION}

Production per tree decreased proportionally with the increase of the interstock length (Figure 1). There was an $18 \%$ reduction in the production per tree with the increase of the EM-9 interstock up to $30 \mathrm{~cm}$. However, it was found that the accumulated production over the years decreased $22.23 \%$ up to the theoretical length of the interstock of $23.7 \mathrm{~cm}$, and from this point, an increase of $6.3 \%$ was observed until the intersotckt of EM-9 of $30 \mathrm{~cm}$ (Figure 2). The productive efficiency accumulated over the years was directly proportional to the interstock length. For plants with $30 \mathrm{~cm}$ interstock, the cumulative productive efficiency was $55 \%$ higher than that accumulated in plants with an EM-9 interstock of $10 \mathrm{~cm}$ in length.

For the productive efficiency of the Imperial Gala apple, it was observed, in all the evaluated harvests, an increasing linear behavior with the increase of the interstock length (Figure 3). Considering the average of the harvests, it was observed for the interstock of EM-9 of $30 \mathrm{~cm}$ increase in productive efficiency in $50 \%$ and $117 \%$ in relation to the section area of the trunk and volume of the canopy, respectively, than the interstockt of 10 $\mathrm{cm}$ in length. Marcon Filho et al. (2009), studying the cultivar Imperial Gala with interstock EM-9, observed that the fertility index also increased with the increase of the interstock length, demonstrating that less vigorous plants 


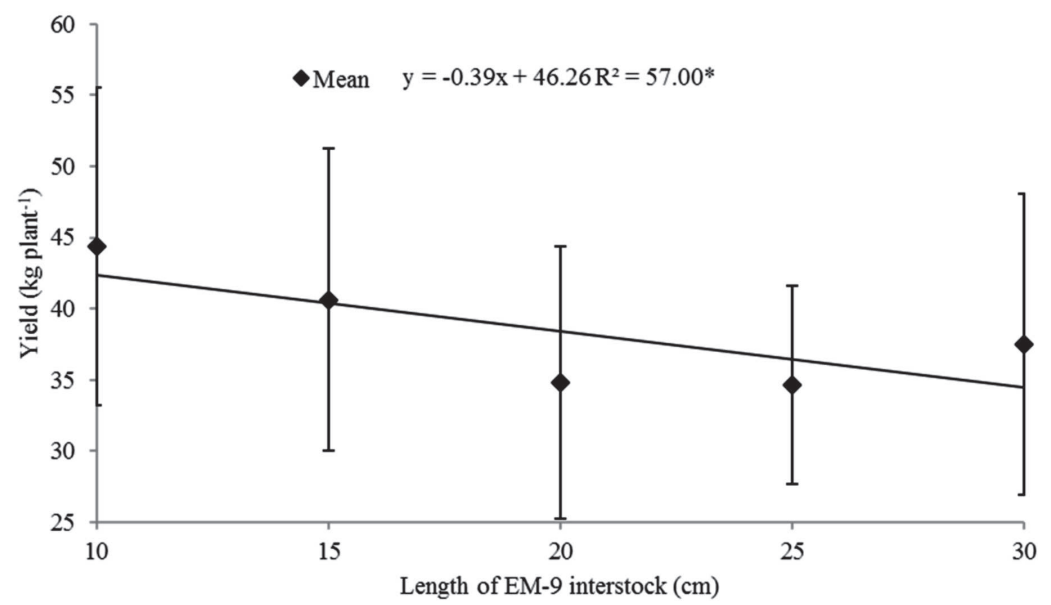

Figure 1: Yield $\left(\mathrm{kg} \mathrm{plant}^{-1}\right)$ of Imperial Gala apple over Marubakaido rootstock in different EM-9 interstock lengths. Data are expressed as average values of five seasons. Vertical bars indicate means \pm standard deviation.

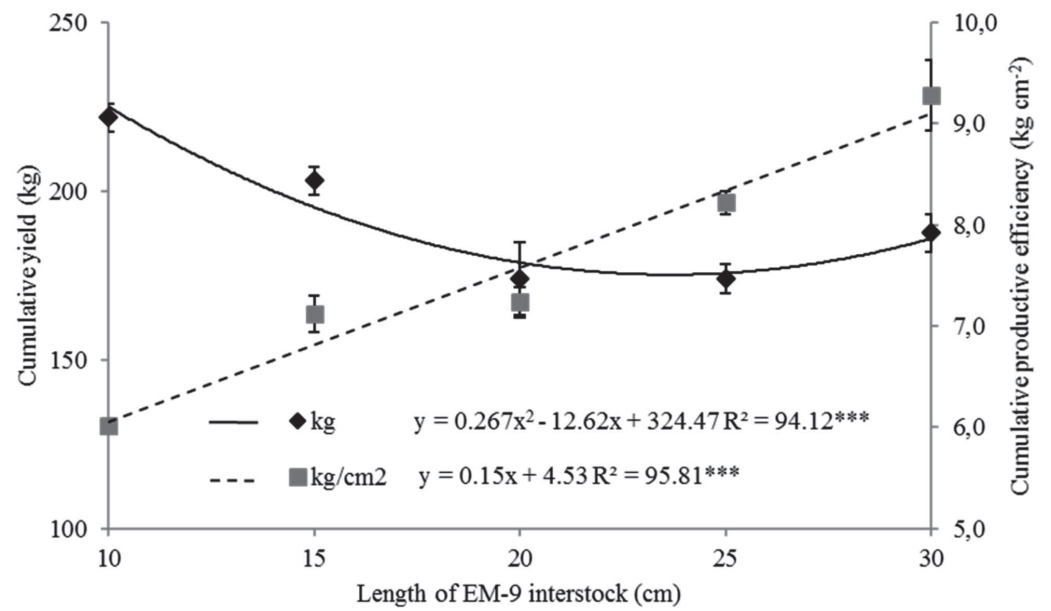

Figure 2: Cumulative yield $\left(\mathrm{kg} \mathrm{plant}^{-1}\right)$ and productive efficiency $\left(\mathrm{kg} \mathrm{cm}^{-2}\right)$ along the 2006, 2008, 2011, 2012 and 2013 seasons of Imperial Gala apple over Marubakaido rootstock in different EM-9 interstock lengths. Vertical bars indicate means \pm standard deviation.

Significance: $* * *=P<0.001$

increase the differentiation of flowering buds. Di Vaio et al (2009) observed that the use of the EM-9 interstock with a length of 10 and $20 \mathrm{~cm}$ with a grafting point at 20 $\mathrm{cm}$ above the ground obtained higher productive efficiency when compared to plants without interstockt. Similar results were reported by Samad et al. (1999), Tojnko et al. (2004), Vercammen et al. (2007) and Tomaz et al. (2010).

Although a reduction in production per tree has been observed, a significant increase in the productive efficiency can be observed with the increase of the interstocklength. According to Fioravanço and Lazzarotto (2012), the increase in the productive efficiency is one of the tendencies of the national pomiculture. The relationship between fruit yield and plant size reflects the efficiency with which photosynthesis products are divided between fruits and vegetative growth. The maximum length of the interstock makes it difficult to translocate the sap upwards and downwards through the vigorous Marubakaido rootstock, thus improving the balance between the vegetative and reproductive part, increasing the canopy efficiency (Martínez-Ballesta et al., 2010).

For the fruit mass variable, no significant effect of the interstock length was observed (Table 1) as reported by Di Vaio et al. (2009), Samad et al. (1999) and Vercammen et al. (2007).

The length of the EM-9 interstock altered the soluble solids (SS) content of the fruits of the Imperial Gala apples (Figure 4). In the 2011 harvest, a linear behavior was observed, with a higher SS for the intersotck length of 30 cm. Samad et al. (1999) observed a higher content of solids in apple trees with interstock and reported that this is possibly due to the carbohydrate content present in the branches in the intergrain treatments and that could be responsible for the higher levels of soluble solids. Because balanced plants tend to provide more carbohydrates to 
fruits than vigorous plants. This may explain the higher solids content for the $30 \mathrm{~cm}$ interstock in this cycle. For the 2012 and 2013 harvest, we observed a quadratic behavior for this variable, with a minimum point obtained with a theoretical length of 17 and $22 \mathrm{~cm}$ from the EM-9 interstock, respectively. However, the values observed in the interstock length range do not vary in order to influence fruit quality in practice.

The most significant effect of interstock length on the characteristics of 'Imperial Gala' apples can be observed in firmer fruit and fruit classification by category. For firmer fruit, apples of greater firmer fruit were observed as the
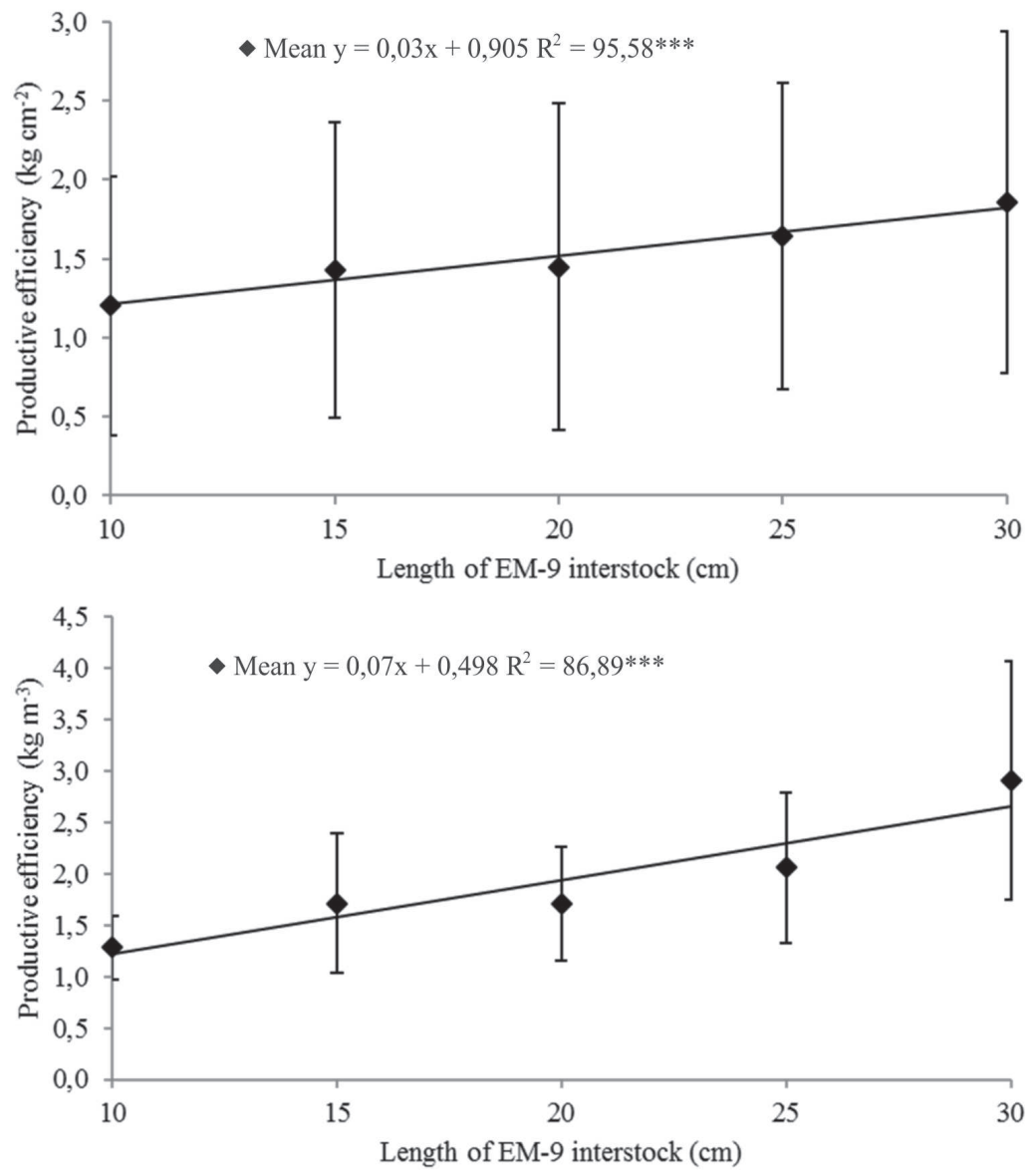

Figure 3: Productive efficiency of Imperial Gala apple over Marubakaido rootstock in different EM-9 interstock lengths. A, in relation the scion trunk area $\left(\mathrm{kg} \mathrm{cm}^{-2}\right), \mathrm{B}$, in relation the canopy volume $\left(\mathrm{kg} \mathrm{m}^{-3}\right)$. Data are expressed as average values of five seasons. Vertical bars indicate means \pm standard deviation.

Significance: $* * *=P<0.001$

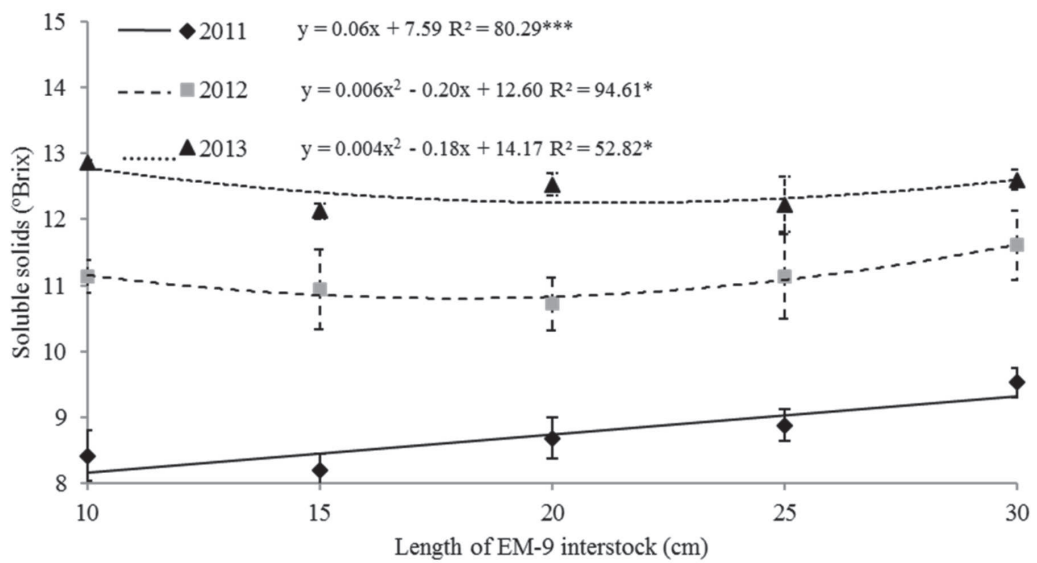

Figure 4: Soluble solids content ( ${ }^{\circ}$ Brix) of Imperial Gala apple over Marubakaido rootstock in different EM-9 interstock lengths. Seasons 2011, 2012 and 2013. Vertical bars indicate means \pm standard deviation.

Significance: $*=P<0.05, * * *=P<0.001$ 
length of the interstock was increased (Figure 5). Samad et al. (1999) reported an increase in firmer fruit in different apple cultivars with EM-9 intersotck in relation to plants without interstock.

For Martínez-Ballesta et al. (2010), nutrient content in plants are strongly influenced by the rootstock, and less vigorous rootstock improve the distribution of photoassimilates, nutrients and hormones, since they decrease the competition between vegetative and productive parts of the plant. According to Marcon Filho et al. (2009), the increase in the length of the EM-9 interstock on vigorous rootstock decreases the shoot growth. In this way the competition for the vegetative part is smaller, directing more nutrients to the fruits and consequently improving the quality of the fruits obtained.
In the classification of fruits by category, a greater number of fruits of category 1 were observed as the length of the EM-9 interstock increased (Figure 6-A). Consequently, reverse behavior was observed for category 3 fruits (Figure 6-B). No influence of the interstock length was observed for category 2 (Table 1 ). This indicates that with the length of the $30 \mathrm{~cm}$ interstock, fruits with more than $60 \%$ red shade are obtained, which have higher market value. According to Jackson (2003), the influence of the rootstock on the color of fruits seems to be mainly a side effect of its direct effects on the vigor of the plants, because less vigorous plants allow greater penetration of light inside the canopy.

The increase of the productive efficiency and improvement in the quality parameters of the fruits of the Imperial Gala apples, with $30 \mathrm{~cm}$ EM-9 interstock, seem to

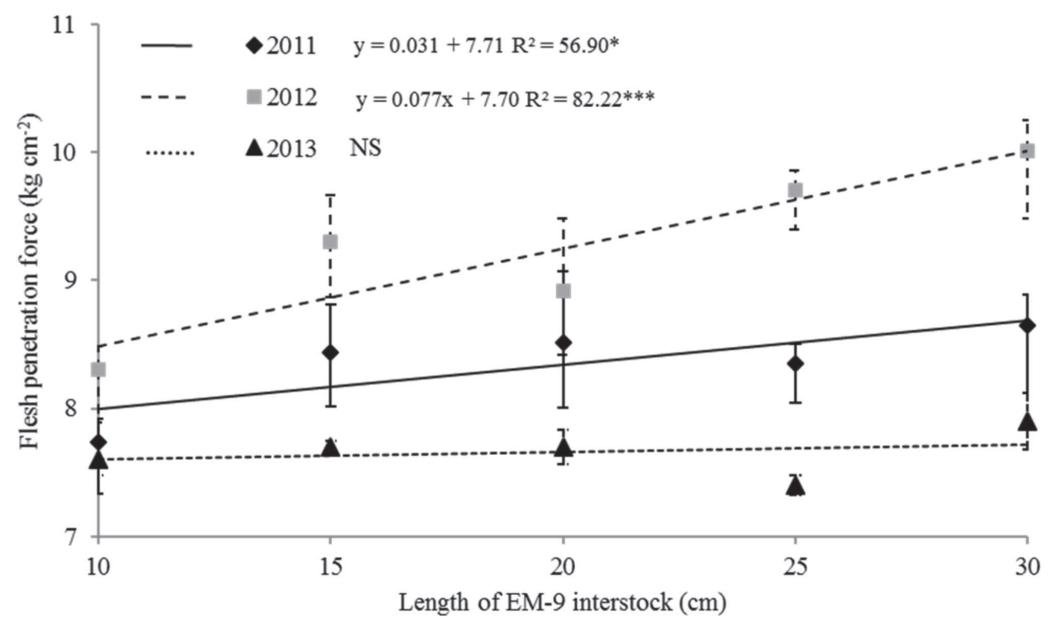

Figure 5: Flesh penetration force $\left(\mathrm{kg} \mathrm{cm}^{-2}\right)$ of Imperial Gala apple over Marubakaido rootstock in different EM-9 interstock lengths. Seasons 2011, 2012 and 2013. Vertical bars indicate means \pm standard deviation.

Significance: $*=P<0.05, * * *=P<0.001, \mathrm{NS}=$ not significance

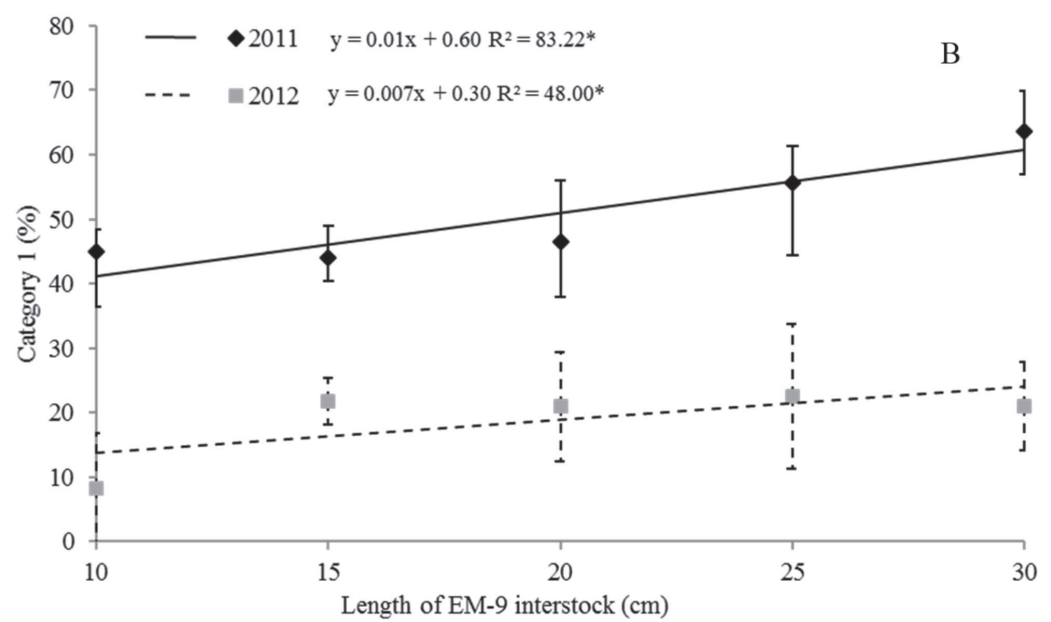

Figure 6: Fruit classification of Imperial Gala apple over Marubakaido rootstock in different EM-9 interstock lengths. A, Category 1; B, Category 3. Seasons 2011 and 2012. Vertical bars indicate means \pm standard deviation.

Significance: $*=P<0.05$

Rev. Ceres, Viçosa, v. 66, n.3, p. 178-183, mai/jun, 2019 
Table 1: Fruit weight (g), fruit classification - Category $2(\%)$ of Imperial Gala apple over Marubakaido rootstock in different EM9 interstock lengths

\begin{tabular}{|c|c|c|c|c|c|c|c|c|}
\hline \multirow{2}{*}{ Parameters } & \multirow{2}{*}{ Season } & \multicolumn{5}{|c|}{ Length of EM-9 interstock (cm) } & \multirow{2}{*}{$\begin{array}{l}\text { ANOVA } \\
P=0.05 \\
\end{array}$} & \multirow{2}{*}{$\begin{array}{c}\text { C.V. } \\
\%\end{array}$} \\
\hline & & 10 & 15 & 20 & 25 & 30 & & \\
\hline \multirow{3}{*}{ Fruit weight $(\mathrm{g})$} & 2011 & 135.97 & 126.31 & 136.58 & 128.24 & 146.53 & NS & 7.5 \\
\hline & 2012 & 97.61 & 92.15 & 96.46 & 91.19 & 93.01 & NS & 14.1 \\
\hline & 2013 & 101.79 & 93.48 & 99.98 & 99.79 & 99.84 & NS & 8.6 \\
\hline \multirow{2}{*}{ Category $2(\%)$} & 2011 & 34.61 & 34.90 & 30.86 & 33.01 & 25.30 & NS & 12.8 \\
\hline & 2012 & 64.16 & 66.16 & 61.75 & 62.23 & 69.89 & NS & 10.7 \\
\hline
\end{tabular}

NS-not significant

justify its use. The combination of this interstock length with a vigorous rootstock allows the production of less vigorous plants and higher quality fruits for commercialization.

\section{CONCLUSIONS}

The EM-9 interstock with $30 \mathrm{~cm}$ lenght provides greater productive efficiency.

Production per plant decreases proportionally to the increase in EM-9 interstock length.

Fruits with greater firmer fruit and red color are obtained with the EM-9 interstock of $30 \mathrm{~cm}$.

The use of different EM-9 interstock lengths did not affect the solids solids content in order to influence the quality of the 'Imperial Gala' apple fruit in practice.

\section{REFERENCES}

Baciu A, Achim G \& Cosmulescu S (2008) Opportunities for reducing the time necessary to obtain tress with interstocks in pear trees. Acta Horticulturae, 800:731-736.

Bhat ZA, Pandit AH, Wani WM \& Rather JA (2011) Effect of Interstock on Juvenility and Tree Size of 'Ambri' Apple. Acta Horticulturae, 903:435-438.

Denardi F (2006) Portaenxertos. In: Empresa de pesquisa agropecuária e extensão rural de santa catarina - epagri. A cultura da macieira. Florianópolis: Epagri, 169-227.

Di Vaio C, Cirillo C, Buccheri M \& Limongelli F (2009) Effect of interstock (M.9 and M.27) on vegetative growth and yield of apple trees (cv. "Annurca"). Scientia Horticulturae, 119:270274

Fioravanço JC \& Lazzarotto JJ (2012) A Cultura da Macieira no Brasil: reflexões sobre produção, mercado e fatores determinantes da competitividade futura. Informações Econômicas, $42: 42-54$

Girardi EA \& Mourão Filho FAA (2006) Production of interstocked 'Pera' sweet orange nursey trees on 'Volkamer' lemon and 'Swingle' citrumelo rootstocks. Scientia Agrícola, 63:05-10.

Gregory PJ, Atkinson CJ, Bengough AG, Else MA, FernándezFernández F, Harrinson RJ \& Schmidt S (2013) Contributions of roots and rootstocks to sustainable, intensified crop production. Journal of Experimental Botany, 64:1209-1222.

Jackson JE (2003) Biology of Apples and Pears. Nova York: Cambridge University, 488p.
Machado AA \& Conceição AR WinStat: sistema de análise estatística para Windows. Versão 2.0. Pelotas: Universidade Federal de Pelotas, 2003.

Marcon Filho JL, Rufato L, Rufato AR, Kretzschmar AA \& Zancan,C (2009) Aspectos produtivos e vegetativos de macieiras cv. Imperial Gala interenxertadas com EM-9. Revista Brasileira de Fruticultura, 31:784-791.

Martínez-Ballesta CM, Alcaraz-López C, Muries B, Mota-Cadenas C \& Carjal M (2010) Physiological aspects of rootstock- scion interactions. Scientia Horticulturae, 127:112-118.

Petri JL, Leite GB, Couto M \& Francescatto P (2011) Avanços na Cultura da Macieira no Brasil. Revista Brasileira de Fruticultura, E: $49-56$.

Rossi A, Rufato L, Kersten E \& Zan-can C (2003) Comportamiento vegetativo del manzano Imperial Gala con diferentes longitudes de interme-diario. Información Técnica Económica Agraria, 99:140-146.

Rufato L, Rossi AR, Giacobbo CL, Fachinello JC \& Gomes FRC (2006) Intergrafting to control vigor of 'Jubileu' peach. Acta Horticulturae, 713:231-236.

Samad A, Mcneil DL \& Khan ZU (1999) Effect of interstock bridge grafting (M9 dwarfing rootstock and same cultivar cutting) on vegetative growth, reproductive growth and carbohydrate composition of mature apple trees. Scientia Horticulturae, 79:23-38.

Scarpare Filho JA, Kluge RA, Victória Filho R, Neto JT 7 Jacomino AP (2000) Comportamento de duas cultivares de pessegueiro com interenxerto da ameixeira 'Januária'. Pesquisa Agropecuária Brasileira, 35:757-765.

Telles CA, Biasi LA, Neto URM \& Peters E (2006) Sobrevivência e crescimento de mudas de pessegueiro interenxertadas. Revista Brasileira de Fruticultura, 28:297-300.

Tojnko S, Cmelik Z \& Zadravec P (2004) Influence of Interstock on Growth and Cropping of 'Red Elstar' Apple. Acta Horticulturae, 658:303-306.

Tomaz ZFP, Lima CSM, Gonçalves MA, Rufato L \& Rufato AR (2010) Crescimento vegetativo, floração e frutificação efetiva do pessegueiro 'Jubileu' submetido a diferentes comprimentos de interenxerto. Pesquisa Agropecuária Brasileira, 45:973-979.

Veloso MEC, Vasconcelos LFL \& Souza VAB (2004) Interstock effect on the vegetative growth of three mango cultivars at Teresina, Piauí state, Brazil. Acta Horticulturae, 645:223-226.

Vercammen J, Daele GV \& Gomand, J (2007) Can Fruit Size and Colouring of 'Jonagold' be Improved by an Interstock? Acta Horticulturae, 732:165-170. 